\title{
DYNAMIC TEST OF A VIADUCT ON THE ORASTIE-SIBIU HIGHWAY
}

Ghindea Cristian Lucian, Senior Lecturer Dr. Eng., Department of Strenth of Materials, Bridges and Tunnels, Technical University of Civil Engineering Bucharest, e-mail: ghindea@utcb.ro

Răcănel Ionuţ Radu, Associate Prof. Dr. Eng., Department of Strenth of Materials, Bridges and Tunnels, Technical University of Civil Engineering Bucharest,e-mail: ionut_racanel@yahoo.com

Cruciat Radu Iuliu, Senior Lecturer Dr. Eng., Department of Strenth of Materials, Bridges and Tunnels, Technical University of Civil Engineering Bucharest, e-mail: $\underline{\text { rcruciat@ utcb.ro }}$

\section{Rezumat}

Încercarea dinamică a podurilor are drept scop determinarea răspunsului acestora la efectele de tip impuls dintre trenul de rulare şi neregularităţile căii. În general, pe durata experimentului se măsoară în timp real acceleraţii sau deformații care ulterior, prin prelucrări succesive, furnizează alte mărimi cum sunt viteze, deplasări, valori ale coeficientului dinamic, precum şi ale fracţiunii din amortizarea critică. Pentru validarea răspunsului podului ca urmare a încercării, mărimile măsurate sunt comparate pe de-o parte cu valori standardizate sau limitate pe baza experienţei de proiectare, iar pe de altă parte cu rezultatele obţinute utilizând modele analitice sau numerice de calcul.

În România, efectuarea încercării dinamice a podurilor este recomandată de standardele în vigoare doar pentru poduri de importanţă mare, executate în soluţii compexe sau speciale sau cu deschideri mari.

Lucrarea de faţă îşi propune să prezinte rezultatele obţinute din măsurătorile realizate cu ocazia efectuării încercării dinamice a unui viaduct amplasat pe tronsonul dintre Orăştie şi Sibiu al autostrăzii A1. Podul are suprastructura realizată în soluţie compusă oţel-beton, grindă continuă pe 12 deschideri : 40+10×60+40m, infrastructura constând în 11 pile cu elevaţie lamelară şi înălţimi cuprinse în intervalul $8.50-24 \mathrm{~m}$.

În lucrare este prezentat şi un model de calcul cu elemente finite cu ajutorul căruia au fost realizate analize dinamice time-history utilizând ca acţiune o funcţie de încărcare de tip impuls. În final sunt comparate şi discutate rezultatele obţinute prelucrând măsurătorile din teren şi cu ajutorul modelului numeric.

Cuvinte cheie: pod, impuls, acceleraţie, conținut în frecvențe, amortizare

\section{Abstract}

Dynamic testing of bridges has as target to establish their response on pulse forces between the wheels and unevenness of road surface. Generally, during the tests, real time 


\section{ROMANIAN JOURNAL OF TRANSPORT INFRASTRUCTURE}

Ghindea Cristian Lucian, Răcănel Ionuţ Radu, Cruciat Radu Iuliu Dynamic test of a viaduct on the Orastie-Sibiu highway

accelerations or deformations are to be measured and which through successive processing methods lead to other data as velocities, displacements, dynamic impact factor, but also the damping ratio. In order to validate the bridge response following testing, the measured data are compared both with allowable limits existing in standards and with the results obtained using analytical or numerical models.

In Romania, the dynamic testing of bridges is recommended by the current standards, only for important bridges, erected in complex or special solutions and also for large span bridges.

The aim of this paper is to outline the results obtained from the on-site measurements during dynamic testing of a viaduct placed on the motorway A1, sector Orăştie-Sibiu. The bridge superstructure is a composite one, continuous girder on 12 spans: $40+10 \times 60+40 \mathrm{~m}$, the substructure consisting in 11 piers with lamellar elevations and variable height in the range $8.50-24 \mathrm{~m}$.

In the paper a finite element model is also presented which was used for time-history analyses using an impulse type load. Finally, the results obtained on the site and using the numerical model are compared and discussed.

Keywords: bridge, impulse, acceleration, frequency content, damping

\section{INTRODUCTION}

Quality monitoring by experimental testing is an important factor in the construction of a bridge or viaduct, regardless of its type, pedestrian, road or railroad. A particular role in the set of experimental tests is represented by the tests carried out prior to the commissioning of the bridges or viaducts, these being called vehicles loading tests and are classified according to the loading type, static and dynamic.

The static or static and dynamic test mode is chosen related to the importance and complexity of the structure and other factors, the span length, the used materials, as well as other factors [1]. The two types of tests are complementary, providing the possibility of obtaining an amount of physical data which can be uses to make complex characterization of behavior of the real structure.

None of the tests has a special significance without a comparison between the experimental and the computational results, generally obtained in the design stages of the structure.

From the point of view of the dynamic test, the comparison with the numerical results can be simplified only to a comparison between the frequency content of the experimentally recorded vibrations and the frequencies resulting from the modal analysis of the structure or one can perform special numerical analyzes for comparison of other physical quantities (maximum displacements, 


\section{ROMANIAN JOURNAL OF TRANSPORT INFRASTRUCTURE}

Ghindea Cristian Lucian, Răcănel Ionuţ Radu, Cruciat Radu Iuliu Dynamic test of a viaduct on the Orastie-Sibiu highway

velocities or accelerations, variations in time of these quantities and others).

In this paper there are presented the dynamic experimental tests, in terms of experimental conditions and results, of a viaduct built on the Orăștie-Sibiu highway at $\mathrm{km} 71+034.82-71+714.82$ [2]. In order to compare the experimental results, a numerical model with FEM was made. By mean of the FEM model the modal shapes and frequencies were obtained and though different time-history analyses, the time variation of the accelerations and peak accelerations were also obtained.

\subsection{The viaduct structural description}

The viaduct is located at $\mathrm{km} 71+034.82-71+714.82$ of the Orăștie-Sibiu motorway and it is composed from two independent superstructures (bridges), one for each direction of movement. The total length of the bridge is $689.30 \mathrm{~m}$ an it is covered with the following sequence of span lengths: $40+10 \times 60+40 \mathrm{~m}$. In plan view, the bridge is curved, with a radius of $990 \mathrm{~m}$ and in elevation has a longitudinal slope between $1.3 \%$ and $4.4 \%$.

The superstructure is a continuous girder with 12 spans, the expansion gap devices are positioned at the ends of the bridge, at the abutment gaps (figure 1). For every superstructure, the roadway has two lanes with a width of $3.50 \mathrm{~m}$ and a safety lane with a $2.75 \mathrm{~m}$ width. The total width of the deck is $12.00 \mathrm{~m}$, with a transversal slope of $2.5 \%$. The infrastructure of every bridge is composed from 11 piers and two abutments. The height of the piers varies between $8.45 \mathrm{~m}$ and $24.00 \mathrm{~m}$.

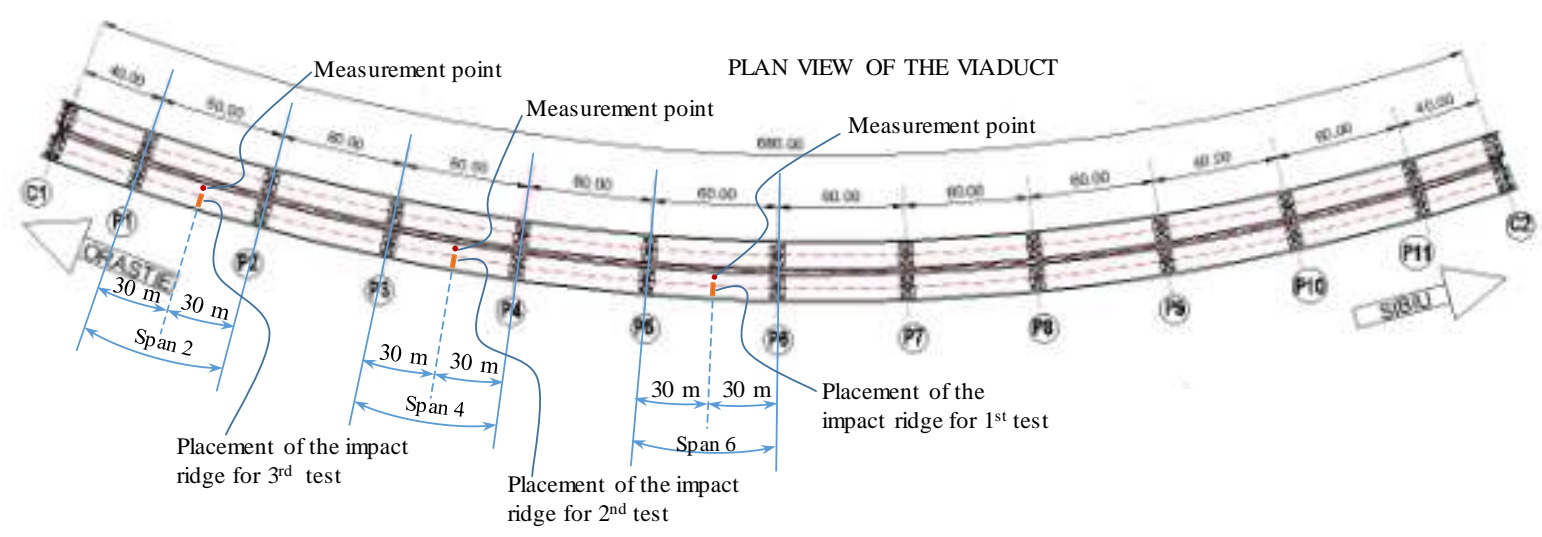

Figure 1. The general plan view of the viaduct, the measurement points position and the placement of the impact ridge 


\section{ROMANIAN JOURNAL OF TRANSPORT INFRASTRUCTURE}

Ghindea Cristian Lucian, Răcănel Ionuț Radu, Cruciat Radu Iuliu Dynamic test of a viaduct on the Orastie-Sibiu highway

\section{MATERIALS AND METHODS}

\subsection{Equipment description and placement}

The experimental measurements were made by recording the vertical accelerations at the roadway level of the deck. The equipment allowed the realtime measurement of the accelerations, as the digital recording of the obtained data (Figure 2).

In order to make the experimental testing, the accelerometers were rigidly fixed to the roadway, accordingly with the specific codes [3], in the immediate neighborhood of the longitudinal axis, through some steel clamps (Figures 2 and 3 ) which can provide an integral transmission of the vibration to the sensors.

For the safety of the measurement, in every measurement point two accelerometers were mounted. The principal accelerometer was mounted in the same cross-section as the ridge used for the induction of the vertical impact force, in the middle of the span. The secondary accelerometer (the control sensor) was mounted laterally at approximately $1.50 \mathrm{~m}$ from the principal sensor.

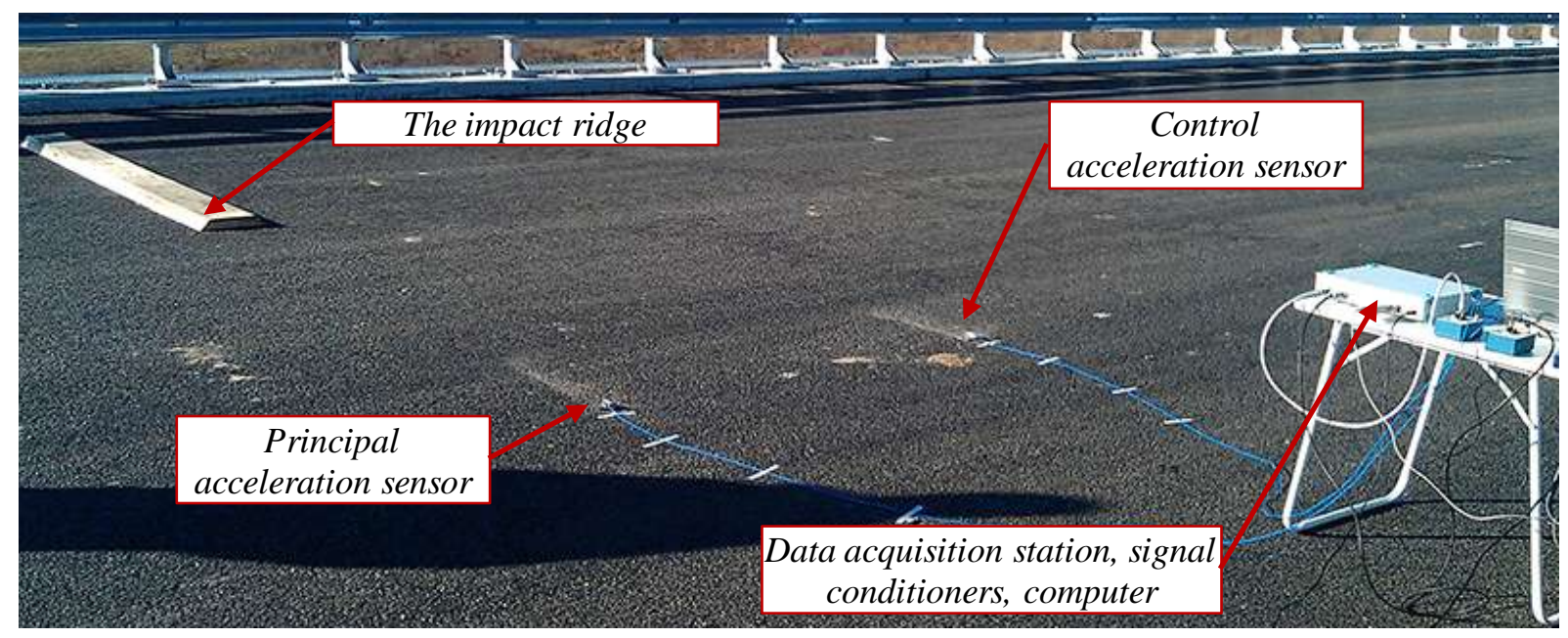

Figure 2. The equipment for the accelerations measurement

\subsection{The description of the test loading}

The dynamic loading was made with a series of trucks loaded with gravel (Figure 4). Every truck had a total mass of approximately 45 tons (Figure 5). The dynamic testing of the bridge was made only with one truck running with a constant speed on the entire length of the bridge, from the passing on the entrance expansion gap until the passing on exit expansion gap. 


\section{ROMANIAN JOURNAL OF TRANSPORT INFRASTRUCTURE}

Ghindea Cristian Lucian, Răcănel Ionuţ Radu, Cruciat Radu Iuliu Dynamic test of a viaduct on the Orastie-Sibiu highway

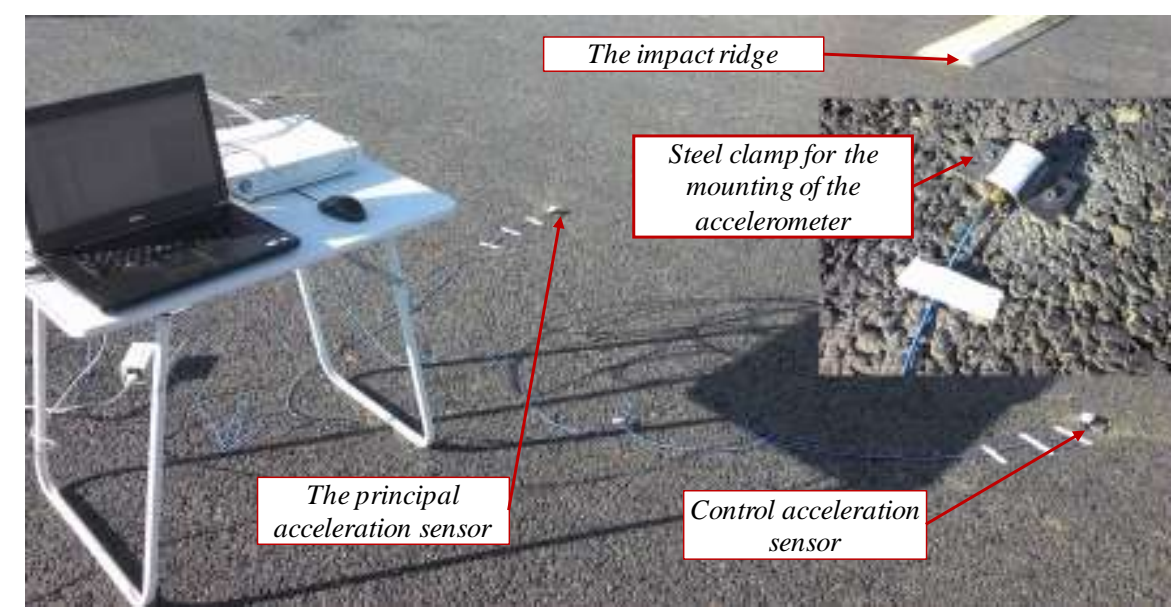

Figure 3. The placement of the acceleration sensors in the $3^{\text {rd }}$ span of the viaduct

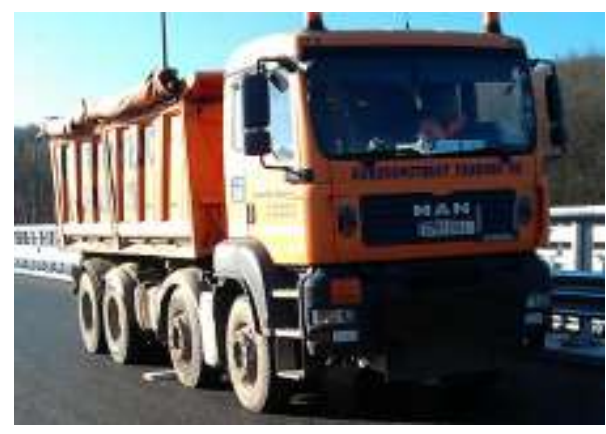

Figure 4. One of the trucks used for the dynamic test

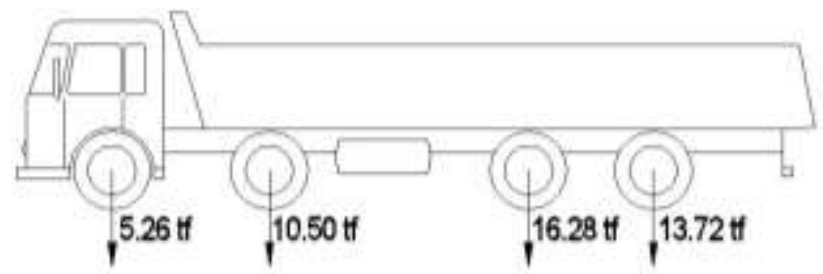

Figure 5. The loading scheme of one of the test trucks

The deck vibrations were measured in real-time, the oscillations being characterized by three phases: the pre-shock phase, the impact loading phase and the after-shock phase, when one can consider that the deck has a free vibration.

According with the testing code requirements [1], the necessary impact force for the dynamic test was obtained through the passing of the test truck over a ridge made from a wood board with standard dimensions $(30 \times 4-300 \mathrm{~cm})$ and two $45^{\circ}$ bevels (Figures 6 and 7). 


\section{ROMANIAN JOURNAL OF TRANSPORT INFRASTRUCTURE}

Ghindea Cristian Lucian, Răcănel Ionuț Radu, Cruciat Radu Iuliu Dynamic test of a viaduct on the Orastie-Sibiu highway

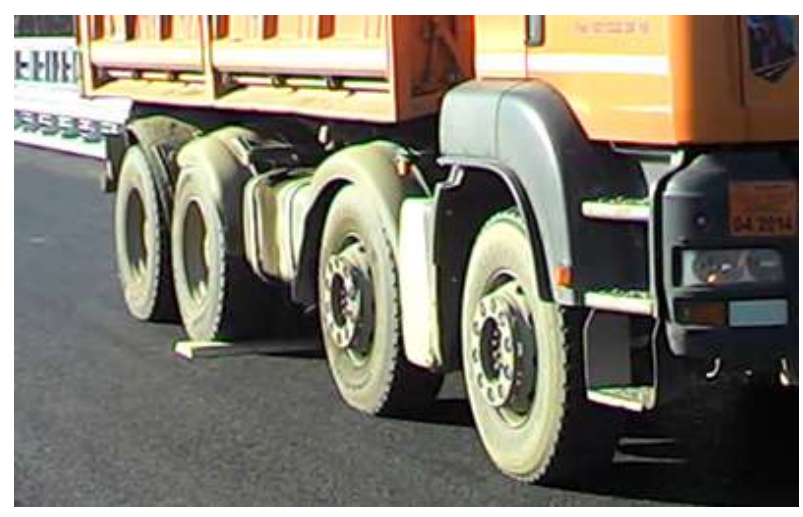

Figure 6. A detail about the passing of the test truck over the impact ridge

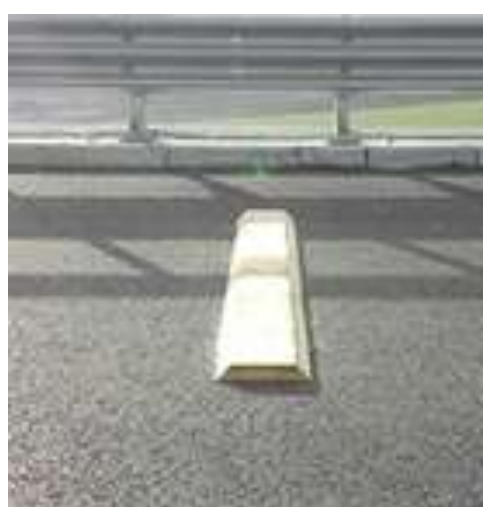

Figure 7. Ridge made from a wood board and $45^{\circ}$ bevels

\subsection{The classification of the experimental tests}

There were made three sets of experimental tests. The test can be classified accordingly with the position of the impact ridge along the bridge. First position of the ridge was in the middle of the $6^{\text {th }}$ span (test no. 1), the second position was in the middle of the $4^{\text {th }} \operatorname{span}($ test no. 2) and, finally, the third position was in the middle of the $2^{\text {nd }} \operatorname{span}($ test no. 3 ).

For every test five loading schemes were applied, corresponding to five speed values of the testing truck running on the bridge, as follows: $10 \mathrm{~km} / \mathrm{h}, 30$ $\mathrm{km} / \mathrm{h}, 50 \mathrm{~km} / \mathrm{h}, 70 \mathrm{~km} / \mathrm{h}, 90 \mathrm{~km} / \mathrm{h}$.

For each test the principal measurement point, called "station 1", was located in the same span and cross-section as the impact ridge and the secondary measurement point, called "station 2", was located in the neighbor span. In Table 1 the correlation between the station ID and the span position is presented, accordingly with the dynamic experimental test classification.

Table 1. The correlation of the measurement points with dynamic tests

\begin{tabular}{|c|c|c|}
\hline \multirow[t]{2}{*}{ Test no. } & \multicolumn{2}{|c|}{ Position of the measurement point } \\
\hline & Station 1 & Station 2 \\
\hline Test 1 & Middle of the $6^{\text {th }}$ span & Middle of the $4^{\text {th }}$ span \\
\hline Test 2 & Middle of the $4^{\text {th }}$ span & Middle of the $6^{\text {th }}$ span \\
\hline Test 3 & Middle of the $2^{\text {nd }}$ span & Middle of the $4^{\text {th }}$ span \\
\hline
\end{tabular}

\subsection{Main principles for experimental data processing}

The load induced on the bridge deck it can be considered as an impact 


\section{ROMANIAN JOURNAL OF TRANSPORT INFRASTRUCTURE}

Ghindea Cristian Lucian, Răcănel Ionuţ Radu, Cruciat Radu Iuliu Dynamic test of a viaduct on the Orastie-Sibiu highway

load. After the impact the deck vibrates freely. After a post recording of the experimental data, one can determine the principal dynamic characteristics of the deck using basic knowledge from dynamics of structures [4], as follows: natural period of vibration of the deck $\left(T_{1}\right)$, respectively the natural vibration frequency $\left(f_{1}\right)$, the logarithmic decrement of the free vibration from which it can be computed the critical damping ratio of the structure.

If one considers a theoretical free vibration, as in figure 8 , assimilated to the free vibration response of a SDOF system, one can determine the previously described characteristics.

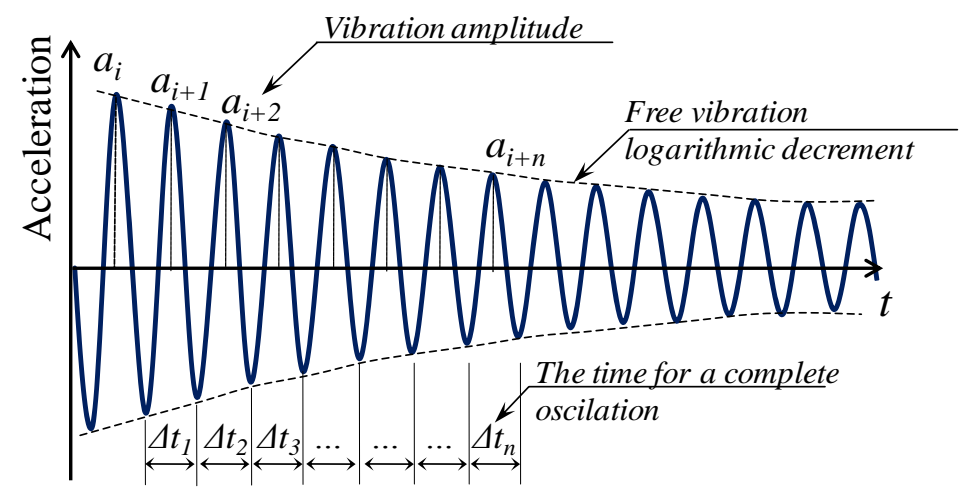

Figure 8. The theoretical free vibration response of a SDOF system

The natural period of vibration of the deck, $T_{1}$, is determined as an average of time intervals for every complete oscillation, and by inversion the natural frequency of the system vibration, $f_{1}$, is determined:

$$
T_{1}=\frac{1}{n} \sum_{i=1}^{n} \Delta t_{i}=\frac{1}{f_{1}}
$$

Taking into account that the structural damping is low, the logarithmic decrement of free vibrations is obtained as an average value against a bigger number of oscillations:

$$
\delta=\frac{1}{n} \ln \frac{a_{i}}{a_{i+n}}
$$

The critical damping ratio of the structural system is determined as a function of the logarithmic decrement of free vibrations,

$$
\xi=\frac{\delta}{\sqrt{4 \pi^{2}+\delta^{2}}}
$$

As result of the increased sensitivity of the measurement equipment, necessary to record all the oscillations from the bridge vibration, expressed through a big number of samples per second, the measured accelerations are 


\section{ROMANIAN JOURNAL OF TRANSPORT INFRASTRUCTURE}

Ghindea Cristian Lucian, Răcănel Ionuț Radu, Cruciat Radu Iuliu Dynamic test of a viaduct on the Orastie-Sibiu highway

influenced by the environmental vibrations and in this special case, by the running of the test trucks on the roadway. In order to identify better the frequencies content of the measured vibrations one made the power spectra of the recorded accelerograms. From a function analytical point of view, the power spectra of an accelerogram provides the transformation of a random function from the time domain into a frequency domain, through a decomposition into different sinus functions with specific frequencies. For the experimental records point of view, as discrete series of values, the sinusoids represent the harmonics of the natural frequencies of the analyzed data.

\section{EXPERIMENTAL RESULTS}

The representation of the result is vast as result of the extent of the experimental test procedure. Taking into account the paper space limitation, the results will be presented only for the test load from span no. 2, for which the numerical analyses were also conducted. Only a part of the test 3 result is presented, more exactly the graphs for the accelerograms recorded in station 1 , positioned in the middle of the $2^{\text {nd }}$ span.

\subsection{Recorded accelerograms}

For all the accelerograms were applied the base-line corrections and filtrations with band-pass filters between $0.10 \mathrm{~Hz}$ and $25 \mathrm{~Hz}$, in order to eliminate the noise outside of the interest bandwidth.

\subsection{Critical damping ratio}

In table 2 there are shown the dynamic characteristics of the bridge resulted from the manual processing of the recorded accelerograms, as stated in paragraph 2.4, and the peak vertical acceleration at the roadway level. 


\section{ROMANIAN JOURNAL OF TRANSPORT INFRASTRUCTURE}

Ghindea Cristian Lucian, Răcănel Ionuţ Radu, Cruciat Radu Iuliu Dynamic test of a viaduct on the Orastie-Sibiu highway

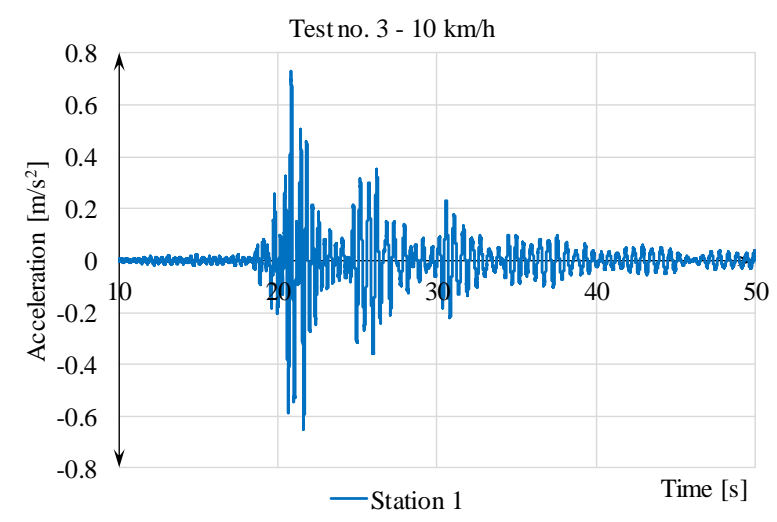

Figure 9. The accelerogram for the component 1 of the $3^{\text {rd }}$ test $(10 \mathrm{~km} / \mathrm{h})$

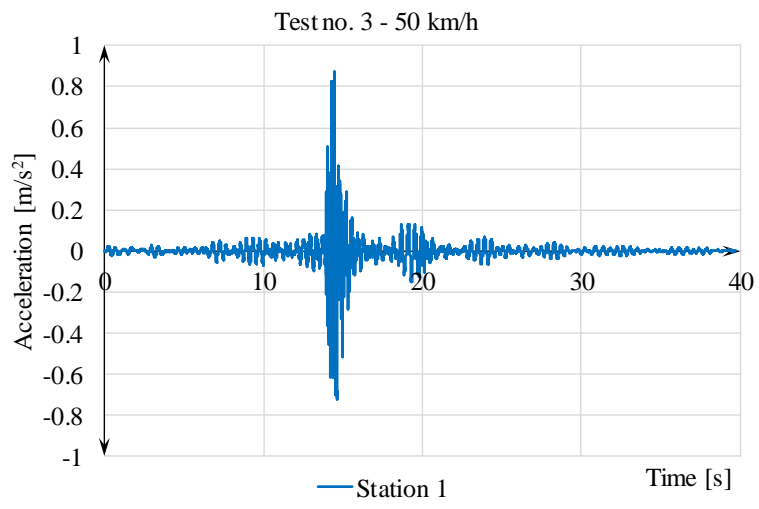

Figure 11. The accelerogram for the component 3 of the $3^{\text {rd }}$ test $(50 \mathrm{~km} / \mathrm{h})$

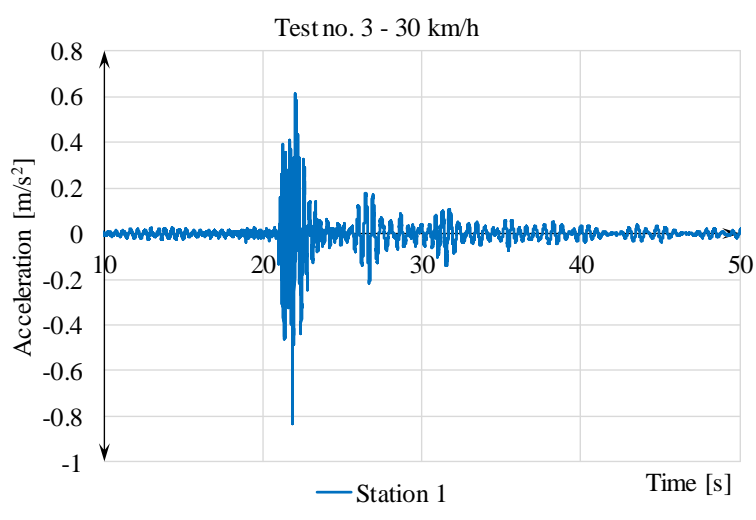

Figure 10. The accelerogram for the component 2 of the $3^{\text {rd }}$ test $(30 \mathrm{~km} / \mathrm{h})$

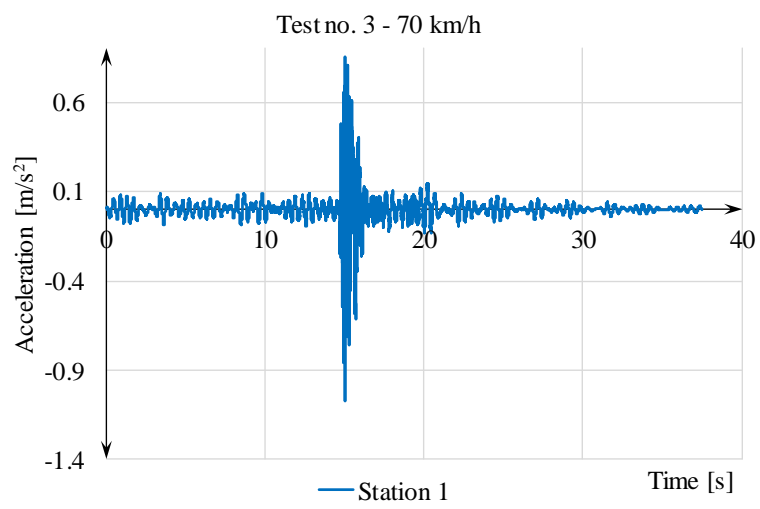

Figure 12. The accelerogram for the component 4 of the $3^{\text {rd }}$ test $(70 \mathrm{~km} / \mathrm{h})$

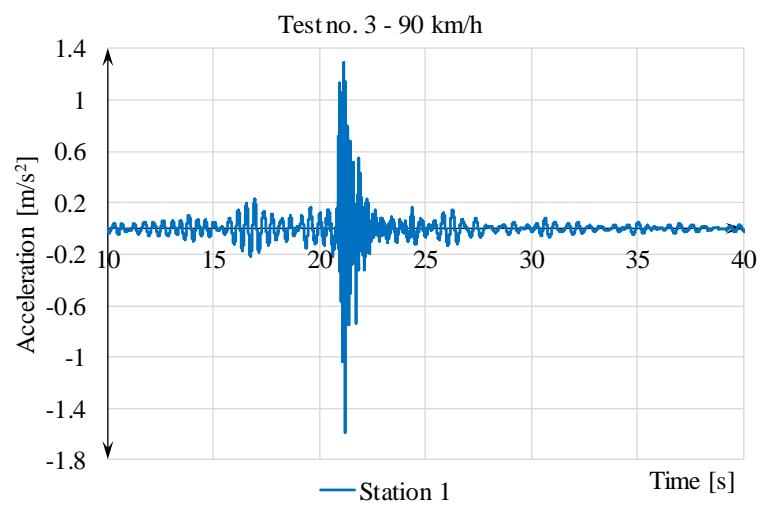

Figure 13. The accelerogram for the component 5 of the $3^{\text {rd }}$ test $(90 \mathrm{~km} / \mathrm{h})$ 


\subsection{Power spectra}

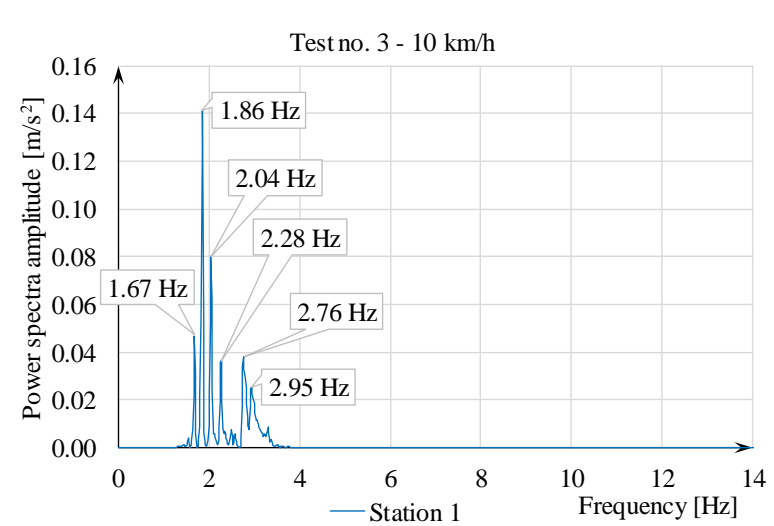

Figure 14. The power spectra of the accelerogram for the component 1 of the $3^{\text {rd }}$ test $(10 \mathrm{~km} / \mathrm{h})$

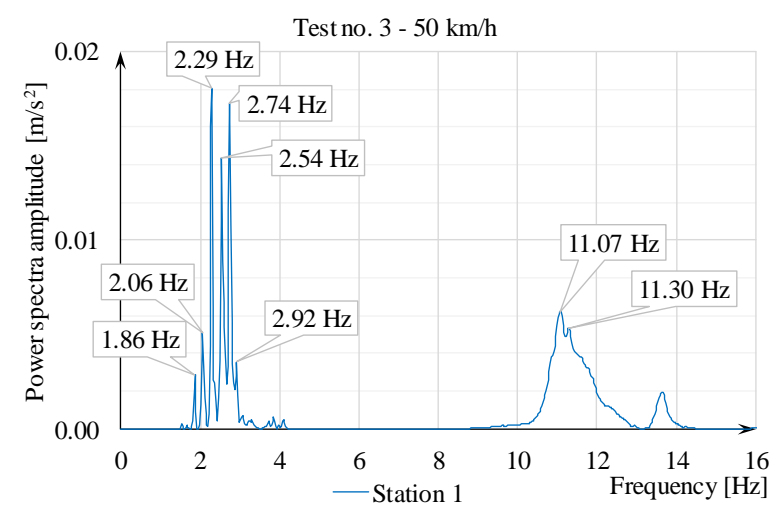

Figure 16. The power spectra of the accelerogram for the component 3 of the $3^{\text {rd }}$ test $(50 \mathrm{~km} / \mathrm{h})$

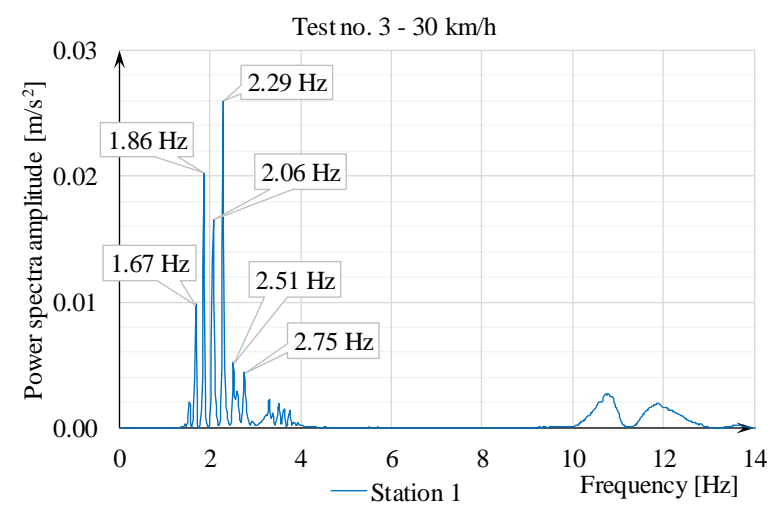

Figure 15. The power spectra of the accelerogram for the component 2 of the $3^{\text {rd }}$ test $(30 \mathrm{~km} / \mathrm{h})$

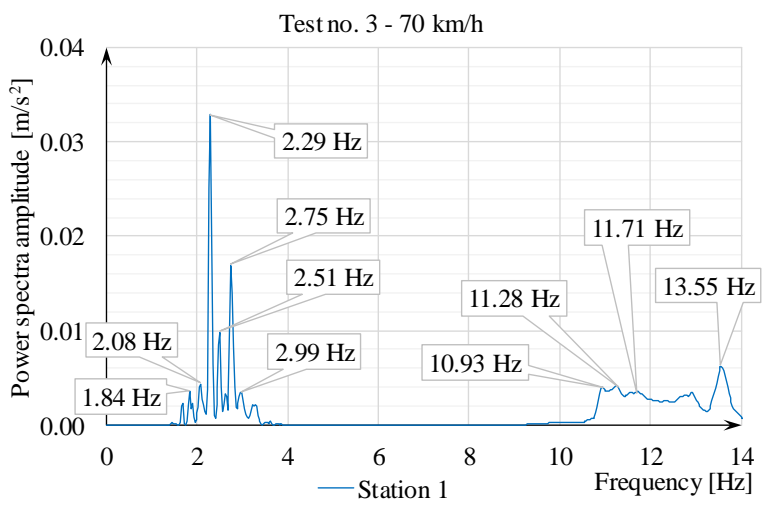

Figure 17. The power spectra of the accelerogram for the component 4 of the $3^{\text {rd }}$ test $(70 \mathrm{~km} / \mathrm{h})$

The critical damping ratio is $6.62 \%$ and it was obtained as an average of the values calculated for all three experimental tests.

The peak acceleration recorded for all considered tests varies between $0.53 \mathrm{~m} / \mathrm{s}^{2}$, at test no. $3-$ load case no. 2 , and $2.23 \mathrm{~m} / \mathrm{s}^{2}$, at test no. $3-$ load case no. 5 . 


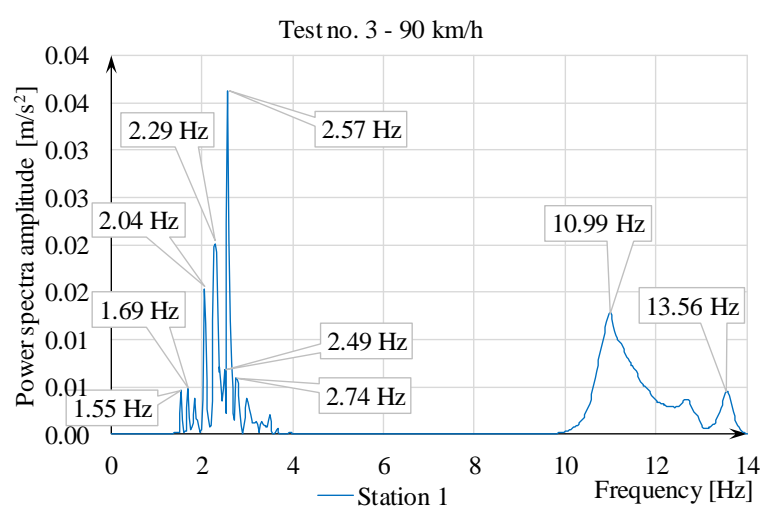

Figure 18. The power spectra of the accelerogram for the component 4 of the $3^{\text {rd }}$ test $(70 \mathrm{~km} / \mathrm{h})$

Table 2. The calculation of the critical damping ratio

\begin{tabular}{|c|c|c|c|c|c|c|c|}
\hline \multirow[b]{2}{*}{ Test } & \multirow[b]{2}{*}{ Load case } & \multirow[b]{2}{*}{ Station } & \multicolumn{4}{|c|}{ Dynamic characteristics } & \multirow{2}{*}{$\begin{array}{c}\text { Peak } \\
\text { acceleration }\end{array}$} \\
\hline & & & $\begin{array}{c}\mathbf{T} \\
{[\mathbf{s}]}\end{array}$ & $\begin{array}{c}\mathbf{f} \\
{[\mathrm{Hz}]}\end{array}$ & $\boldsymbol{\delta}$ & $\begin{array}{c}\xi \\
{[\%]}\end{array}$ & \\
\hline \multirow{5}{*}{$\begin{array}{l}\text { Test } \\
\text { no. } 3\end{array}$} & $\mathrm{C} 1-10 \mathrm{~km} / \mathrm{h}$ & S1 & 0.81 & 1.23 & 0.480 & $7.64 \%$ & $0.69 \mathrm{~m} / \mathrm{s}^{2}$ \\
\hline & $\mathrm{C} 2-30 \mathrm{~km} / \mathrm{h}$ & S1 & 0.41 & 2.44 & 0.465 & $7.40 \%$ & $0.53 \mathrm{~m} / \mathrm{s}^{2}$ \\
\hline & $\mathrm{C} 3-50 \mathrm{~km} / \mathrm{h}$ & S1 & 0.35 & 2.86 & 0.449 & $7.15 \%$ & $0.95 \mathrm{~m} / \mathrm{s}^{2}$ \\
\hline & $\mathrm{C} 4-70 \mathrm{~km} / \mathrm{h}$ & S1 & 0.36 & 2.78 & 0.370 & $5.89 \%$ & $0.93 \mathrm{~m} / \mathrm{s}^{2}$ \\
\hline & $\mathrm{C} 5-90 \mathrm{~km} / \mathrm{h}$ & S1 & 0.35 & 2.86 & 0.528 & $8.40 \%$ & $2.23 \mathrm{~m} / \mathrm{s}^{2}$ \\
\hline
\end{tabular}

\section{NUMERICAL MODEL OF THE BRIDGE DECK}

In order to determine the behavior of the structure, taking into account the deck assembly, from structural and static point of view (continuous girder with 12 spans and expansion gaps positioned only at the ends of the bridge), a 3D finite elements model was made. There were used 4 nodes shell finite elements with bending and membrane behavior. The shape and the dimensions of the finite elements (the element thickness) were chosen in order to model, as closely as possible, the geometry and the dimensions of the real structure. In the modeling stage one considered the variability of the concrete slab, from the upper side of the deck, and the steel sheets from which the cross-section of the steel elements is built.

Because of the structural assembly composition with bearing support devices putted on every pier, the behavior of the superstructure, in terms of cross-sectional forces, stresses and vertical displacements of the deck, isn't 


\section{ROMANIAN JOURNAL OF TRANSPORT INFRASTRUCTURE}

Ghindea Cristian Lucian, Răcănel Ionuţ Radu, Cruciat Radu Iuliu Dynamic test of a viaduct on the Orastie-Sibiu highway

significantly influenced by the presence of the infrastructure in the model, the infrastructure wasn't modelled with FEM. In Figure 19 the FEM model of the deck is shown.

A modal analysis of the model was performed, considering that the mass source is provided only by the self-weight of the structure. In Figure 20 the first vertical translation modal shape is presented; the vibration mode corresponds with $10^{\text {th }}$ mode which had the most important vertical translation modal participation factor. In table 2 are presented the natural frequencies of the first $19^{\text {th }}$ modes, with vertical translation modal participation factor, which there are compared with the experimentally determined frequencies.

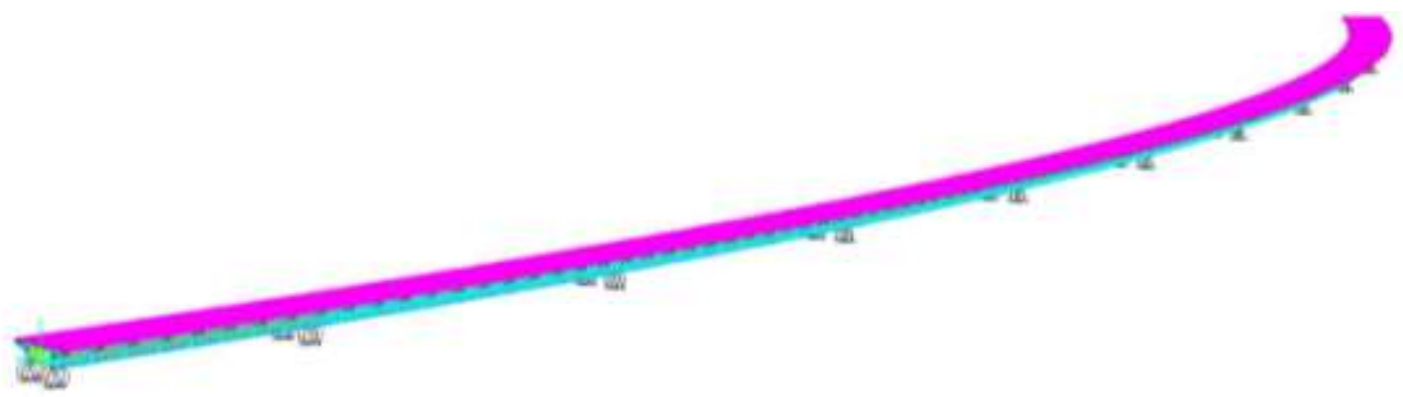

Figure 19. 3D finite element model of the bridge deck

Figure 20. $10^{\text {th }}$ modal shape $\left(f_{10}=2,89 \mathrm{~Hz}\right.$ - modal participation factor $\left.40,10 \%\right)$

Beside the modal analysis made on the previously presented numerical model, other two time-history analyses were made, considering the dynamic load induced by the test load truck which was running on the roadway with 10 $\mathrm{km} / \mathrm{h}$ and $30 \mathrm{~km} / \mathrm{h}$, respectively.

In Figures 21 and 22 are present the acceleration time-history of a node positioned in the middle cross-section of the $2^{\text {nd }}$ span of the bridge. The frequencies content of those accelerograms is presented also in Table 3. 


\section{ROMANIAN JOURNAL OF TRANSPORT INFRASTRUCTURE}

Ghindea Cristian Lucian, Răcănel Ionuţ Radu, Cruciat Radu Iuliu Dynamic test of a viaduct on the Orastie-Sibiu highway

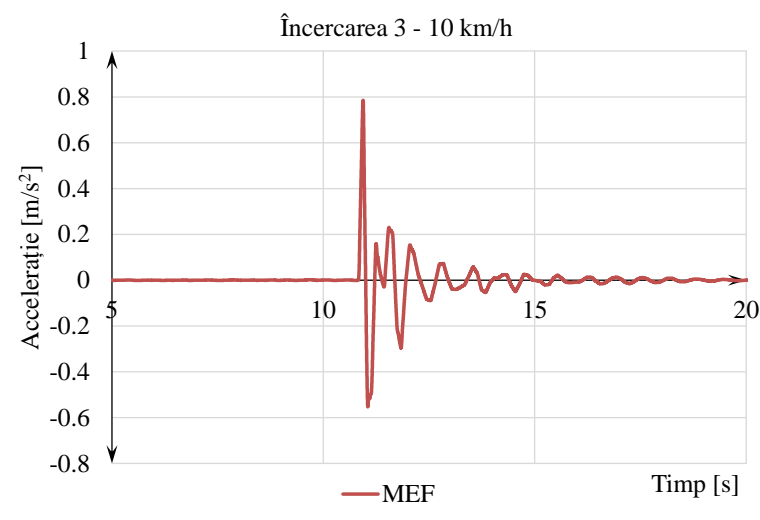

Figure 21. Acceleration time-history obtained from FEM analysis equivalent to test no. 3 - load case no. $1(10 \mathrm{~km} / \mathrm{h})$

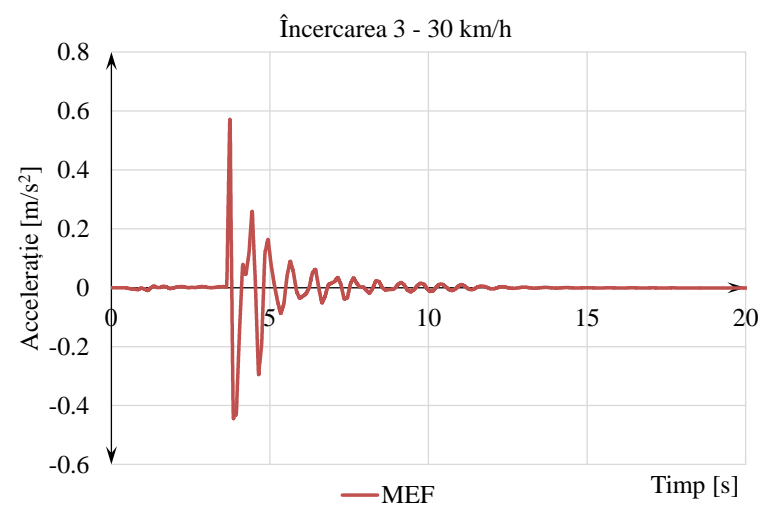

Figure 22. Acceleration time-history obtained from FEM analysis equivalent to test no. 3 - load case no. $2(30 \mathrm{~km} / \mathrm{h})$

\section{CONCLUSIONS}

If the experimental tests are made accordingly with a standard dynamic test [1], the dynamic response of the bridge is generally different from the theoretical free vibration response of a structure subjected to an impact loading. The vibration frequencies induced by the test load trucks can be found usually in the same bandwidth as the main vibration frequencies of the bridge and can't be separately identified.

In Table 3 are compared the vibration frequencies of the deck as resulted from the modal analysis of the bridge numerical model with the ones resulted from experimental testing of the structure. Using this centralization, one can observe that from all three test procedures the minimum values of the frequencies are between $1.44 \mathrm{~Hz}$ and $1.46 \mathrm{~Hz}$, values close to or equal to the natural frequency obtained from the modal analysis $(\mathrm{f} 1=1.46 \mathrm{~Hz})$.

In the frequencies content obtained experimentally, for every performed test, one can identify frequencies in the neighborhood of the modal frequency corresponding to the $10^{\text {th }}$ mode which it is the mode with the biggest vertical translation modal participation factor. This frequency is $f_{10}=2.86 \mathrm{~Hz}$ and the modal participation factor of this mode is $40.10 \%$.

From the point of view of the vibrations damping, the experimental determined critical damping factor is $6.62 \%$. This is bigger than the typical value, of 5\%, used at the dynamic design of the composite structures, steel and reinforced concrete or simply reinforced concrete structures. This may be due as result of the particular structural characteristics of the bridge and the obtained value can be considered favorable for the damping of the vibrations induced by 


\section{ROMANIAN JOURNAL OF TRANSPORT INFRASTRUCTURE}

Ghindea Cristian Lucian, Răcănel Ionuţ Radu, Cruciat Radu Iuliu Dynamic test of a viaduct on the Orastie-Sibiu highway

the running of the vehicles on the bridge

From the point of view of the time-history of the accelerations obtain from numerical analysis and experimental tests one can observe that the obtained peak accelerations are close in the corresponding cases, $0.78 \mathrm{~m} / \mathrm{s}^{2}$ compared with $0.69 \mathrm{~m} / \mathrm{s}^{2}$ at $10 \mathrm{~km} / \mathrm{h}$ and $0.57 \mathrm{~m} / \mathrm{s}^{2}$ compared with $0.53 \mathrm{~m} / \mathrm{s}^{2}$ at $30 \mathrm{~km} / \mathrm{h}$. The frequency content is practically similar in both cases, numerical and experimental.

Table 3. Frequencies content comparison between experimental tests and numerical modal analysis

\begin{tabular}{|c|c|c|c|c|c|c|c|c|c|c|}
\hline \multirow{3}{*}{$\begin{array}{c}\text { Frequencies } \\
\text { bandwidth }\end{array}$} & \multirow{3}{*}{ 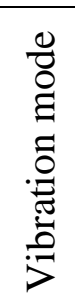 } & \multirow{3}{*}{ 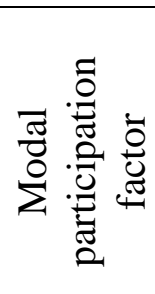 } & \multirow{3}{*}{$\begin{array}{l}f_{F E M} \\
{[\mathrm{~Hz}]}\end{array}$} & $\begin{array}{r}f_{\text {time }} \\
{[1}\end{array}$ & & \multicolumn{5}{|c|}{$f_{\text {experimental }}[\mathrm{Hz}]$} \\
\hline & & & & \multicolumn{2}{|c|}{ FEM model } & \multicolumn{5}{|c|}{ Test no. 3} \\
\hline & & & & $\begin{array}{c}10 \\
\mathrm{~km} / \mathrm{h}\end{array}$ & $\begin{array}{c}30 \\
\mathrm{~km} / \mathrm{h}\end{array}$ & $\mathrm{T} 1$ & $\mathrm{~T} 2$ & T3 & $\mathrm{T} 4$ & T5 \\
\hline \multirow{4}{*}{$1 \div 2 \mathrm{~Hz}$} & 1 & $0.02 \%$ & 1.46 & \multirow{4}{*}{$\begin{array}{l}1.50 \\
1.67 \\
1.85\end{array}$} & \multirow{4}{*}{$\begin{array}{l}1.39 \\
1.54 \\
1.74 \\
1.89\end{array}$} & \multirow{4}{*}{$\begin{array}{l}1.67 \\
1.69 \\
1.84 \\
1.86\end{array}$} & \multirow{4}{*}{$\begin{array}{l}1.56 \\
1.67 \\
1.70 \\
1.85 \\
1.86\end{array}$} & \multirow[t]{4}{*}{1.86} & \multirow[t]{4}{*}{1.84} & \multirow{4}{*}{$\begin{array}{l}1.54 \\
1.55 \\
1.69\end{array}$} \\
\hline & 2 & $0.01 \%$ & 1.52 & & & & & & & \\
\hline & 3 & $0.18 \%$ & 1.72 & & & & & & & \\
\hline & 4 & $0.06 \%$ & 1.89 & & & & & & & \\
\hline \multirow{7}{*}{$2 \div 3 \mathrm{~Hz}$} & 5 & $0.49 \%$ & 2.08 & \multirow{7}{*}{$\begin{array}{l}2.06 \\
2.27 \\
2.54\end{array}$} & \multirow{7}{*}{$\begin{array}{l}2.24 \\
2.44 \\
2.69 \\
2.95\end{array}$} & \multirow{7}{*}{$\begin{array}{l}2.04 \\
2.28 \\
2.74 \\
2.76 \\
2.93 \\
2.95\end{array}$} & \multirow{7}{*}{$\begin{array}{l}2.06 \\
2.29 \\
2.51 \\
2.64 \\
2.72 \\
2.75\end{array}$} & \multirow{7}{*}{$\begin{array}{l}2.06 \\
2.29 \\
2.54 \\
2.62 \\
2.73 \\
2.74 \\
2.91 \\
2.92\end{array}$} & \multirow{7}{*}{$\begin{array}{l}2.08 \\
2.26 \\
2.29 \\
2.33 \\
2.51 \\
2.71 \\
2.75 \\
2.99\end{array}$} & \multirow{7}{*}{$\begin{array}{l}2.04 \\
2.29 \\
2.49 \\
2.57 \\
2.69 \\
2.74 \\
2.88 \\
2.98\end{array}$} \\
\hline & 6 & $0.03 \%$ & 2.31 & & & & & & & \\
\hline & 7 & $2.79 \%$ & 2.49 & & & & & & & \\
\hline & 8 & $0.30 \%$ & 2.69 & & & & & & & \\
\hline & 9 & $5.70 \%$ & 2.76 & & & & & & & \\
\hline & 10 & $40.10 \%$ & 2.86 & & & & & & & \\
\hline & & & & & & & & & & \\
\hline \multirow{3}{*}{$3 \div 4 \mathrm{~Hz}$} & 11 & $0.00 \%$ & 3.04 & \multirow[t]{3}{*}{3.06} & \multirow{3}{*}{$\begin{array}{l}3.57 \\
3.80\end{array}$} & \multirow[t]{3}{*}{-} & \multirow[t]{3}{*}{-} & \multirow[t]{3}{*}{-} & \multirow[t]{3}{*}{3.05} & \multirow{3}{*}{$\begin{array}{l}3.06 \\
3.28\end{array}$} \\
\hline & 12 & $1.47 \%$ & 3.52 & & & & & & & \\
\hline & 13 & $16.28 \%$ & 3.63 & & & & & & & \\
\hline \multirow{4}{*}{$4 \div 10 \mathrm{~Hz}$} & 14 & $0.39 \%$ & 4.01 & & & - & - & - & - & - \\
\hline & 15 & $0.01 \%$ & 4.68 & & & & & & & \\
\hline & 16 & $2.45 \%$ & 6.30 & & & & & & & \\
\hline & 17 & $0.42 \%$ & 6.68 & & & & & & & \\
\hline & 18 & $0.10 \%$ & 12.85 & & & 10.78 & 11.07 & 10.93 & 10.99 & - \\
\hline $10 \div 14 \mathrm{~Hz}$ & 19 & $22.66 \%$ & 13.37 & & & & 11.30 & 11.28 & 13.56 & \\
\hline 10.1718 & & & & & & & 13.69 & $\begin{array}{l}11.71 \\
13.55\end{array}$ & & \\
\hline
\end{tabular}

Although the visual appearance of time-history graphs is significantly different in the compared cases, numerical and experimental, this aspect can be 


\section{ROMANIAN JOURNAL OF TRANSPORT INFRASTRUCTURE}

Ghindea Cristian Lucian, Răcănel Ionuț Radu, Cruciat Radu Iuliu Dynamic test of a viaduct on the Orastie-Sibiu highway

explained by the lack of environmental noise and the by the simpler response in the case of the numerical model (in part this is due the missing of non-structural elements in the numerical model) and by the fact that the modelled loads didn't induce supplementary vibrations into the structure.

In the particular conditions of the experimental tests in which there were measured only accelerations, for a reduced number of points located on the deck of the bridge, the determination of the impact coefficient (one of the dynamic characteristics imposed by STAS 12504-86 [1] to be determined) is practically impossible. Considering that the numerical model is virtually compatible with the real structure, using different FEM analysis the response of the bridge can be extrapolated. In this way one can obtain different characteristics of interest, as for example the impact coefficient.

\section{REFERENCES}

[1]. STAS 12504-86: "Railway bridges, viaducts and walkways. Testing of superstructures with test actions", IRS, Bucharest, 1986.

[2]. "Static and dynamic tests at bridges - between $71+035.82-71+715.82$ (object 3) and $\mathrm{km} 73+040.32-73+285.32$ (object 5), at the Orăștie - Sibiu highway, batch 4", UTCB Contract no. 205/2013.

[3]. ISO 5348:1998: "Mechanical mounting of accelerometers", International Organization for Standardization, Geneva, 1998.

[4]. A. K. CHOPRA: "Dynamics of Structures", third ed., Prentice Hall, New Jersey, 2006 